\title{
ANALISIS KONVENSI HAK ANAK DALAM MENJAMIN PERLINDUNGAN KESEHATAN ANAK DI INDONESIA (STUNTING)
}

\author{
Muhammad Haddad Fadlyansyah \\ Fakultas Hukum, Universitas Trunojoyo Madura \\ Muhammadhaddad2508@gmail.com
}

\begin{abstract}
Abstrak
Anak adalah anugerah Tuhan Yang Maha Esa, yang perlu dilindungi harkat dan martabatnya serta dijamin hak-haknya untuk tumbuh dan berkembang sesuai dengan kodratnya. Permasalahan kesehatan anak dalam hal gizi merupakan salah satu prioritas PBB. Kasus stunting merupakan kasus balita yang memiliki panjang atau tinggi badan yang kurang jika dari standar pertumbuhan anak dari WHO. Indonesia menempati urutan ke 5 dari 10 negara dengan angka stunting tertinggi di dunia. Pasal 24 ayat (2) Konvensi Hak Anak telah mengatur bahwa "setiap negara-negara peserta akan mengusahakan pelaksaan sepenuhnya dari hak ini dan khususnya akan mengambil langkah-langkah yang tepat ...."
\end{abstract}

Kata Kunci: Hak Anak, Stunting, Konvensi Hak Anak.

\begin{abstract}
Abstrac
Children are a gift from God, who needs to be protected by their dignity and rights to be guaranteed to grow and develop in accordance with their nature. Child health problems in terms of nutrition is one of the UN priorities. Stunting is a case of toddlers who have a length or height less than the WHO child growth standards. Indonesia ranks 5 highest stunting rates in the world. Article 24 paragraph (2) Convention on the Rights of the Child stipulates that "each participating country will endeavor to fully implement this right and in particular take appropriate steps ..."
\end{abstract}

Keywords: Child Rights, Stunting, Convention on the Rights of the Child 


\section{PENDAHULUAN}

\section{A. Latar Belakang}

Anak merupakan anugerah pemberian dari Tuhan Yang Maha Esa sehingga hak untuk tumbuh dan berkembang sesuai dengan kodratnya harus dilindungi. Sebagai generasi penerus bangsa, anak harus mendapatkan pelayanan secara maksimal. Nilai yang tertanam dalam anak dijadikan norma universal, karena anak dinilai sebagai manusia yang utuh, sehingga hak asasi nya harus dilindungi. Pandangan seperti ini membuat orang dewasa harus bertanggung jawab penuh terhadap anak di dunia. Perlindungan anak demikian merupakan bagian dari pelaksanaan Hak Asasi Manusia.

Kepedulian terhadap anak dimulai pada tahun 1920 setelah Perang Dunia I. Karena anak dan perempuan menjadi kaum yang dianggap lemah pada saat itu. Eglantyne Jebb salah satu aktivis yang mengembangakan butir-butir pernyataan tentang hak anak yang pada tahun 1923 diadopsi Save the Children Fund International Union (Muhammad Joni dan Zulchina Z. Tanamas, $1996: 8$ ).

Hak Asasi Manusia mengalami perkembangan yang cukup pesat yaitu pada tanggal 10 Desember 1948 dikeluarkannya Deklarasi Universal Hak Asasi Manusia (DUHAM). Hak Anak dalam DUHAM terdapat dalam Pasal 25 ayat (2) DUHAM yang menyatakan bahwa "Ibu dan anak- anak berhak mendapatkan perhatian dan bantuan khusus. Semua anak, baik yang dilahirkan di dalam maupun di luar perkawinan, harus menikmati perlindungan sosial yang sama”.

Tidak cukup dengan mengeluarkan DUHAM saja dalam melindungi hak anak, para aktivis melakukan tuntutan kepada PBB yang kemudian pada tanggal 20 November 1959 dengan dikeluarkannya Deklarasi Hak Anak menyatakan bahwa anak harus mendapatkan jaminan tumbuh kembang dengan sehat dan untuk mencapai tujuan tersebut harus ada perawatan dan perlindungan khusus bagi si anak dan ibunya. Anak berhak mendapat gizi 
yang cukup, perumahan, rekreasi dan pelayanan kesehatan.

Dalam Konvensi Hak Anak termuat 54 pasal yang berdasarkan materi hukumnya mengatur mengenai hak anak dan mekanisme implementasi hak anak oleh negara sebagai pihak yang meratifikasi Konvensi tersebut. Materi hukum nya memuat empat materi pokok hak-hak anak, sebagai berikut:

a. Hak kelangsungan hidup (Survival Right), yang meliputi hak untuk melestarikan dan mempertahankan hidup (the right of life) dan hak untuk memperoleh kesehatan tertinggi serta perawatan yang sebaikbaiknya (the right to the highest standart of health and medical care attainable)

b. Hak perlindungan (protection right), yang meliputi hak perlindungan dari diskriminasi, tidak kekerasan dan ketelantaran bagi anak yang tidak mempunyai keluarga dan anakanak pengungsi,

c. Hak untuk tumbuh kembang (development rights), meliputi segala bentuk Pendidikan (formal dan non-formal) dan hak untuk standar hidup yang layak bagi perkembangan fisik, mental, spiritual, moral dan sosial anak.

d. Hak berpartisipasi (participation rights), meliputi hak anak untuk menyatakan pendapat dalam segala hal yang mempengaruhi anak (the right of the child to express his opinion in all matters affecting the child).

Pasal 24 ayat (1) Konvensi Hak Anak berbunyi "Negara-negara peserta mengakui hak anak untuk menikmati status kesehatan tertinggi yang dapat dicapai dan untuk memperoleh saranasarana perawatan penyakit dan pemulihan kesehatan. Negara-negara peserta akan berusaha untuk menjamin bahwa tak seorang anakpun yang akan dirampas haknya untuk memperoleh pelayanan perawatan kesehatan seperti itu". Ayat (2) dalam pasal ini berbunyi "Negara-negara peserta akan mengusahakan pelasanaan sepeniuhnya dari hak ini dan khususnya akan mengambil langkahlangkah yang tepat: 
a. Untuk memperkecil angka kematian bayi dan anak;

b. Untuk memastikan pengadaan bantuan medis dan perawatan kesehatan yang diperlakukan untuk anak dengan tekanan pada pengembangan perawatan kesehatan dasar;

c. Untuk memberantas penyakit dan kekurangan gizi, termasuk kerangka perawatan kesehatan dasar, melalui penerapan teknologi yang mudah diperoleh dan pengadaan makanan bergizi yang memadai serta air minum yang bersih, dengan mempertimbangkan bahaya dan risiko pencemaran lingkungan;

d. Untuk memastikan perawatan kesehatan sebelum dan sesudah melahirkan bagi ibu-ibu;

e. Untuk memastikan bahwa semua golongan masyarakat, terutama para orangtua dan anak-anak, diberi informasi, bisa memperoleh Pendidikan dan mendapat dukungan dalam penggunaan pengetahuan dasar tentang kesehatan dan gizi anak, manfaat-manfaat dari pemberian air susu ibu, kesehatan dan penyehatan lingkungan dan pencegahan kecelakaan;

f. Untuk mengembangkan perawatan kesehatan pencegahan, bimbingan untuk para orangtua dan Pendidikan dan pelayanan keluarga berencana.

Dari sekian banyak Hak Anak yang harus dilindungi oleh negara-negara, salah satu Hak yang menjadi prioritas adalah masalah kesehatan Kesehatan merupakan hal yang menjadi prioritas selain pendidikan dalam Konvensi Hak Anak, karena anak harus diberikan gizi yang baik serta perawatan kesehatan yang benar agar anak dapat tumbuh dan berkembang sesuai dengan umur nya.

Permasalahan kesehatan anak dalam hal gizi merupakan salah satu prioritas PBB terkait kesehatan anak. Dewasa ini kita mengenal istilah yang namanya Stunting.

Stunting (kerdil) adalah kondisi dimana balita memiliki panjang atau 
tinggi badan kurang dari anak-anak seusianya. Kondisi seperti ini dilihat dari panjang atau tinggi badan anak yang lebih dari minus dua standar pertumbuhan anak dari WHO. Balita yang mengalami stunting dapat terjadi karena beberapa faktor seperti kondisi sosial ekonomi, gizi ibu saat hamil, kesakitan pada bayi, dan kurangnya asupan gizi pada bayi. Dimasa mendatang bayi yang terkena stunting akan mengalami kesulitan perkembangan fisik dan kognitif yang optimal (Didik Budijanto, 2018 : 2)

Stunting dapat terjadi di dalam 1.000 hari pertama dari konsepsi hingga dua tahun pertama kehidupan anak (World Health Organization: 2013), dan menghasilkan kehilangan tinggi yang tak bisa dibalikkan, kekebalan tubuh melemahsistem dan peningkatan risiko yang signifikan penyakit dan kematian. (Olofin,2013)

Pengerdilan juga terkait dengan perkembangan psikososial suboptimal, memiliki dampak jangka panjang pada fungsi intelektual, kinerja sekolah, pendapatan masa depan, risiko obesitas dan penyakit kronis (The Global
Nutrition Report. 2014). Nutrisi ibu yang tidak mencukupi menyebabkan kehamilan antar generasi siklus kegagalan pertumbuhan: ibu yang kekurangan gizi - seringkali miskin dan di bawah umur - melahirkan bayi kecil-untuk-usia kehamilan dan berat lahir rendah yang berisiko Stunting dan pengembangan suboptimal. Keadaan ini menciptakan jebakan kemiskinan untuk anak-anak, masyarakat dan bangsa (Prendergast, A. J \& J. H. Humphrey, 2014: 250265), diperparah oleh masalah keadilan yang memengaruhi perempuan dan anak-anak yang rentan terhadap kekurangan gizi (United Children's Fund,2013).

Data Pemantauan Status Gizi tahun 2017 mencatat sebanyak $22,2 \%$ atau sekitar 150,8 juta balita di dunia mengalami stunting. Di Indonesia angka kejadian stunting mencapai prosentase 29,6\% di tahun 2017 naik sebesar $2,1 \%$ dari tahun 2016. Survei ini dilaksanakan sebagai monitoring dan evaluasi kegiatan dan capaian program.

Dalam paparan Doddy Izwandy 
mengatakan bahwa Indonesia menempati peringkat ke 5 dengan jumlah balita yang mengalami stunting dengan prosentase sebesar 37\%, di peringkat pertama terdapat negara India dengan prosentase sebesar $48 \%$ (Doddy Izwardy: 2019). Dari data tersebut dapat dikatakan bahwa permasalahan stunting merupakan permasalahan luar biasa, karena berdampak pada gizi anak dalam bertumbuh dan berkembang sebagaimana mestinya.

WHO sebagai organisasi internasional terkait masalah kesehatan mengambil alih peran yang sangat penting dalam hal ini selain UNICEF sebagai organisasi internasional terkait masalah anak-anak. Dua organisasi Internasional tersebut tidak bisa menghilangkan kasus stunting ini tanpa bantuan negara-negara peserta

Konvensi Hak Anak, peran negara-negara peserta dalam menerapkan kebijakannya sesuai dengan kemampuan negaranya masing-masing.

B. Rumusan Masalah

Adapun rumusan masalah yang dibahas dalam tulisan ini adalah Bagaimana implementasi Konvensi Hak Anak dalam kasus stunting di Indonesia?

\section{PEMBAHASAN}

Pasal 6 ayat (1) Konvensi Hak Anak berbunyi "Negara-negara peserta mengikuti bahwa setiap anak memiliki hak yang melekat atas kehidupan”. Hak Kesehatan merupakan salah satu hak yang melekat pad anak ataupun orang dewasa. Salah satu Hak Kesehatan bagi anak adalah terpenuhinya gizi serta nutrisi anak, sehingga tidak mengakibatkan stunting terhadap anak.

Pasal 27 ayat (1) Konvensi Hak Anak menjelaskan bahwa "Negaranegara peserta mengakui hak setiap anak atas taraf hiduo yang layak bagi pengembangan fisik, mental, spiritual, moral dan sosial anak". Berlandaskan pasal tersebut seharusnya negaranegara peserta mengambil langkahlangkah yang tepat guna mengatasi masalah stunting di Indonesia.

Indonesia merupakan salah satu 
negara pihak dalam Konvensi Hak Anak yang telah meratifikasi Konvensi Hak Anak melalui Keputusan Presiden 1990 yang kemudian dibuat UndangUndang No 23 tahun 2002 tentang Perlindungan Anak dan Perubahan Undang-Undang No 35 tahun 2014 atas Undang-Undang No 23 tahun 2002 tentang Perlindungan Anak.

Pasal 44 ayat (1) UU No. 35 tahun 2014 tentang perlindungan anak berbunyi "Pemerintah dan Pemerintah Daerah wajib menyediakan fasilitas dan menyelenggarakan upaya kesehatan yang komprehensif bagi Anak agar setiap Anak memperoleh derajat kesehatan yang optimal sejak dalam kandungan”. Dalam pasal ini juga dijelaskan bahwasanya masyarakat juga berperan adil dalam menjadi pendukung dari penyelenggara negara.

Sejauh ini pemerintah pusat melalui Menteri kesehatan ataupun Departemen Kesehatan Republik Indonesia beserta IDI telah membuat langkah-langkah guna menurunkan angka stunting di Indonesia, terdapat 5 pilar dalam menurunkan stunting di
Indonesia;

a. Komitmen dan Visi Pimpinan Tertinggi Negara

b. Kampanye Nasional berfokus pada pemahaman, perubahan perilaku, komitmen politik dan akuntabilitas

c. Konvergensi, koordinasi dan konsolidasi program nasional, daerah dan masyarakat

d. Mendorong kebijakan"Nutritional Food Security”

e. Pemantauan dan Evaluasi (Doddy Izwardy, 2019 : 23)

Selain pemerintah pusat dan pemerintah daerah serta masyarakat Indonesia, terdapat organisasi internasional yang bisa dilibatkan dalam masalah stunting ini, seperrti organisasi internasional WHO sebagai organisasi internasional dibawah PBB yang mengawasi masalah kesehatan dan UNICEF yang mengawasi permasalahan tentang anak-anak

\section{PENUTUP}

Isu stunting merupakan salah satu isu internasional yang harus sama-sama kita 
selesaikan bersama. Peran suatu negara dalam mengambil kebijakan terakit masalah ini harus disesuaikan juga dengan keadaan negaranya, apakah mereka termasuk negara yang berkembang atau belum berkembang. Kemampuan ini merupakan tolak ukur bagi negara-negara peserta dalam memberantas atau setidaknya memberikan jaminan perlindungan kesehatan bagi anak anak.

Indonesia sejauh ini sudah meratifikasi Konvensi Hak Anak yang kemudian ditransformasikan kedalam undang-undang no 35 tahun 2014 tentang Perlindungan Anak. Dengan adanya undang-undang ini pemerintah lebih konsen kepada perlindungan anak, baik ketika anak masih dalam kandungan atau bahkan ketika ia sudah dilahirkan, dengan cara memastikan bahwa pasokan pangan kita tersedia sampai pelosok negeri.

Secara regulasi Indonesia sudah bagus dengan mengeluarkan beberapa undang-undang selain terkait anak Indonesia juga mengeluarkan undangundang tentang kesehatan, dari dua undang-undang ini Indonesia sudah kuat dalam hal regulasi, tapi sayangnya tidak diikuti dengan pengimplementasian nya yang baik.
Angka stunting pada anak masih besar dan bahkan Indonesia menempati 5 besar negara terkait masalah stunting.

Dibutuhkan kerja sama seluruh stakeholder baik pusat maupun daerah, serta masyarakat Indonesia dan organisasi-organisasi internasional dalam menangani kasus ini. Kerjasama ini bisa dilakukan dengan cara $M o U$ dengan WHO ataupun UNICEF untuk bersama-sama membantu permaslahan stunting di Indonesia.

Sesuai amanat Konvensi Anak dalam pasal 24 ayat (1) bahwa setiap negara peserta mengakui hak anak untuk menikmari status kesehatan tertingi dan amanat dalam pasal 27 ayat (1) negara- negara peserta mengakui hak setiap anak atas taraf hidup yang layak bagi pengembangan fisik, mental, spiritual, moral dan sosial anak 
Daftar Pustaka

Deklarasi Universal Hak Asasi

Manusia

Data Pemantauan Status Gizi (PSG) pada tahun 2017

Konvensi Hak Anak (Convention of the Right Child)

Olofin, I., et al., 'Associations of Suboptimal Growth with All Cause and Cause Specific Mortality in Children Under Age 5: A pooled analysis of 10 prospective studies', PLoS One, vol. 8, no. 5), e64636, 2013.

Paparan Ir. Doddy Izwardy (Direktur Gizi Masyarakat) pada tanggal 22 Februari 2019 di Hotel Luwansa

Prendergast, A. J., and J. H. Humphrey, 'TheStunting Syndrome in Developing Countries', Paediatric and International Child Health, vol. 34 , no. 4, 2014

The Global Nutrition Report: Actions and accountability to advance nutrition and sustainable development, 2014.
Undang-Undang No 35 tahun 2014 tentang perlindungan anak

Unicef Perwakilan Indonesia. 1996, Pengembangan Hak Anak Pedoman Pelantikan tentang Konvensi Hak Anak, Jakarta, hlm.8. Selanjutnya dapat dilihat dalam Muhammad Joni dan Zulchina Z. Tanamas, Aspek Hukum

United Nations Children's Fund, 'Improving Child Nutrition: The achievable imperative for global progress', 2013.

World Health Organization, 'World Health Assembly Global Nutrition Targets 2025: Stunting policy brief', 2013 
